\title{
Entrepreneurship from a Developmental Science Perspective
}

\author{
Martin Obschonka* and Rainer K. Silbereisen \\ Department of Developmental Psychology and Center for Applied Developmental Science, \\ Friedrich-Schiller-University Jena, Jena, Germany
}

Due to worldwide social, political, and economic change (Silbereisen \& Chen, 2010), entrepreneurship has become a key topic of our time (Hisrich, LanganFox, \& Grant, 2007). We understand entrepreneurship as starting and growing one's own business (or, more broadly, as the identification, evaluation, and exploitation of opportunities, Shane, 2012). Globalization, post-industrial society, rapid technological progress, the deregulation of the labor market in many countries, political shifts towards liberal economies (e.g., in the former Eastern Bloc), and the increasing individualization of the life course have together contributed to an era of entrepreneurship. At the individual level, entrepreneurship has become a central competence to succeed in a working life where, in view of the economic challenges and changing landscapes of work, proactive, self-responsible, creative, and competitive behaviors have become crucial assets and where starting one's own business, and creating something new by entrepreneurial means and innovation, is a promising, albeit risky, job alternative for many people. At the societal level, entrepreneurship (and innovative growthoriented startups in particular) is considered a driver of economic and technological development, innovation, and job creation. In view of this growing relevance at

\footnotetext{
*Address for correspondence

Dr. Martin Obschonka, Department of Developmental Psychology and Center for Applied Developmental Science, Friedrich-SchillerUniversity Jena, Am Steiger 3/1, D-07743 Jena, Germany. E-mail: martin.obschonka@uni-jena.de
}

different levels, it is not surprising that both scholars and policymakers have called for enhanced efforts in researching and promoting entrepreneurship (Hisrich et al., 2007; The World Bank, 2010; World Economic Forum, 2009).

A scholarly field of investigation that has already witnessed considerable growth across the past three decades, entrepreneurship research targets (partly interrelated) topics such as (1) entrepreneurial career choice, (2) opportunity recognition, creation, and evaluation, (3) the venture creation process, (4) innovation, (5) habitual entrepreneurship, and (6) entrepreneurial success and failure. Although the field has made considerable progress in terms of consistent definitions and quality standards in empirical studies, it is still developing and in search of an overarching "consensus about the domain of the field, its boundaries, purposes, areas of focus, or theoretical base" (Shane, 2012, p. 12). For example, there is increasing interest at looking beyond profit-oriented businesses towards broader topics such as social and public entrepreneurship; towards what Sarasvathy and Venkataraman (2011) term a "social force" that drives social change. Although a multi- and interdisciplinary research area, entrepreneurship research is traditionally viewed as a sub-field of economics and management, but other disciplines and approaches such as psychological theories are increasingly considered too (e.g., in the study of entrepreneurial cognitions and decision making). This is also documented in the persistent growth of the 
field, not only in terms of number of scientific journals and published studies but also in terms of diversity (and combination) of approaches in empirical studies, which calls for integrative meta theories. The new area of entrepreneurial genetics (Nicolaou, Shane, Cherkas, Hunkin, \& Spector, 2008), which introduced a biological perspective, is an example of this growing diversity.

Despite this growing diversity, the vast majority of studies in this field are conducted by scholars with a background in economics or management, so that the increasing variety of approaches may mainly reflect their openness towards theories from other disciplines (e.g., psychology or genetics) and not so much an increasing interest among researchers from other backgrounds. Arguably, stimulating an interest for this research field among this broader group of scientists seems worthwhile for several reasons that go beyond the increasing general relevance of the topic. As stated above, entrepreneurship research, by its very nature, is a multi- and interdisciplinary field of investigation (including but not limited to economic, psychological, sociological, legal, political, and geographical perspectives), and the field is explicitly open for (and even calls for) novel perspectives from outside that further research and practice in this area and that contribute to its distinctiveness and development (Sarasvathy \& Venkataraman, 2011). Entrepreneurship has the potential to be an interesting arena for researchers from other fields dealing with general aspects of (1) human cognitions, decisions making, behavior, and performance under conditions of uncertainty and risk, (2) human agency, or (3) processes behind the emergence of new ideas and opportunities that create economic, personal, or social value. These issues are major topics in the contemporary social sciences (e.g., Brandtstädter, 2006; Kahnemann, 2011; Shane, 2012).

Although social and institutional aspects are, without a doubt, central factors of starting and growing a new business, many entrepreneurship researchers agree that the most central unit of investigation is the (potential) entrepreneur. It is argued that this is the key agent whose human agency, decisions, strategies, and behaviors matters, and through which opportunities, which are so central for the entrepreneurial process, are discovered, recognized, or created. This perspective calls for theories and empirical research that puts this single agent and the entrepreneurial mindset (e.g., personality characteristics, competences, knowledge, skills, cognitions, beliefs, and attitudes that underlie entrepreneurial behavior) in the focus, without neglecting the relevance of the context (e.g., the social or institutional context) because it is a truism that mind and behavior can only be fully understood when taking the context into account (Bronfenbrenner, 1979; Silbereisen \& Chen, 2010).

In their seminal theorizing on the making of an entrepreneur, McClelland (1961) and others (e.g., Dyer, 1994; Krueger, 2007) have stressed that each (potential) entrepreneur has a developmental history reaching back to childhood, which is also illustrated by anecdotal evidence in numerous biographies of business founders (e.g., Isaacson, 2011). While such a developmental perspective clearly seems to be necessary in entrepreneurship research, practice, policy, and education (e.g., when designing measures aiming to promote entrepreneurial mindsets), surprisingly little is known about the developmental aspects of entrepreneurship (e.g., early precursors in childhood and adolescence; underlying developmental processes). Systematic research on this issue is very scarce, and this applies for both theory development and empirical studies.

There is a clear indication, however, that a developmental perspective, which already figures prominently in related research fields such as expert performance (Ericsson \& Charness, 1994) and human capital (Heckman, 2006), should be added to the diversifying agenda of entrepreneurship research. Decades of research have made it clear that vocational development starts as early as in childhood and is driven by an ongoing interaction between biological dispositions, changing individual characteristics, and changing contexts (Super, 1980; Vondracek, Lerner, \& Schulenberg, 1986). Numerous longitudinal studies showed occupational outcomes in adulthood (e.g., career choice and job performance) to be predictable by early characteristics (e.g., child temperament, adolescent competencies) and to be linked with age-graded developmental processes (e.g., competence growth, personality development) (e.g., Clausen, 1991). Finally, public measures aimed at developing and implementing entrepreneurship programs in schools and universities already seem to follow such a developmental view (e.g., by targeting basic business knowledge and entrepreneurial skills among school children to promote the development of an entrepreneurial mindset, World Economic Forum, 2009). Unfortunately, given the lack of research on individual development toward (successful) entrepreneurship in adulthood, the empirical underpinning for such measures is scarce. Only recently have empirical studies devoted to entrepreneurial development emerged, indicating that entrepreneurship can be understood as a developmental outcome; as a result 
of a developmental history reaching back to the formative years (i.e., childhood and adolescence) (e.g., Falck, Heblich, \& Luedemann, 2012; Obschonka, 2011; Schmitt-Rodermund, 2004, 2007; Zhang \& Arvey, 2009).

This is the background to this Thematic Issue, which puts the focus on a person's entrepreneurial development, which we broadly define as those successive and systematic changes, occurring across a person's life course, that make an (successful) entrepreneurial career more likely. The Thematic Issue consists of six articles, which underwent a regular double-blind peer review process (each article was reviewed by at least two external reviewers, followed by a revision of the article; the revision was then again examined by the Action Editors). Probably for the first time, this Thematic Issue brings together researchers from different backgrounds (e.g., developmentalists, economists, psychologists, and sociologists) studying entrepreneurial development from various perspectives. To explain the selection of the articles, we want to refer to our Life Span Model of Entrepreneurial Development (Fig. 1).

The model was inspired by a modern understanding of developmental science and life span psychology, according to which human development, which is a lifelong process characterized by the orchestration of gains and losses, is understood as a complex system involving biological, psychosocial, behavioral, and contextual factors that interact (Baltes, Reuter-Lorenz, \& Rösler,
2006; Lerner, 2006). The model acknowledges that there could be different possible developmental trajectories leading to (successful) entrepreneurship in adulthood, which is consistent with two basic principles of human development, namely equifinality (different starting points in development can lead to the same outcome) and multifinality (the same starting point can lead to different developmental outcomes). The model is further based on the rich research in vocational development across the life span, which emphasizes (a) the importance of the formative years, (b) plasticity in vocational development, (c) human agency, and (d) the relevance of the changing ecology in which vocational development over the life span takes place. The concrete empirical foundation of this particular model comes from recent entrepreneurship studies that either analyzed prospective longitudinal data (e.g., following the participants through childhood, adolescence, and adulthood) or retrospective longitudinal data (e.g., surveying established business founders and following back their developmental history) (e.g., Falck et al., 2012; Obschonka, Silbereisen, \& Schmitt-Rodermund, 2010, 2011; Schmitt-Rodermund, 2004, 2007; Zhang $\&$ Arvey, 2009). These promising findings indicate the relevance of a developmental-contextual perspective on entrepreneurship, with a special focus on (1) the formative years, (2) life-stage appropriate development and developmental tasks, and (3) the interplay between biological, psychosocial, behavioral, and contextual factors.

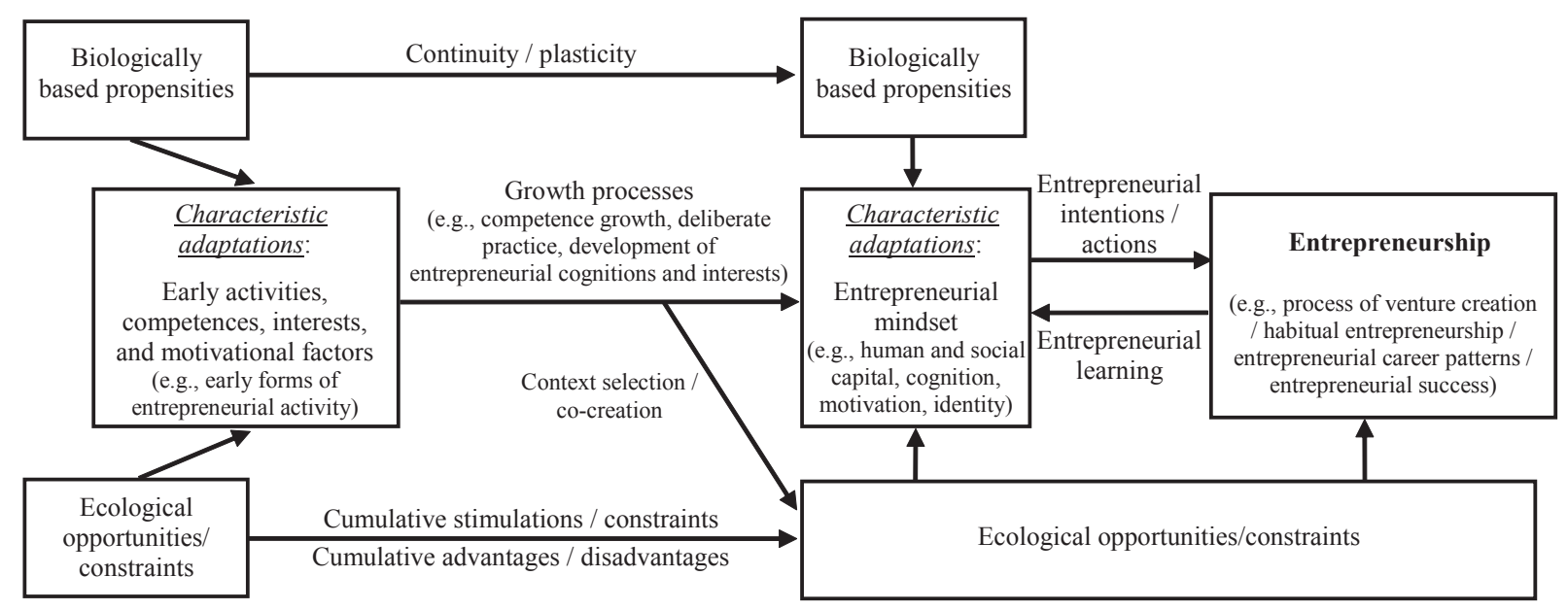

Childhood $/$ Āolescence

Working Life

Figure 1. Life Span Model of Entrepreneurial Development. 
Specifically, the model understands entrepreneurship as a developmental outcome in that it describes the effect of biologically based propensities (e.g., genetic make-up, temperament, broad personality traits, Rothbart, 2011) and ecological opportunities and constraints (e.g., stimulating early environments such as promotive early role models, parenting, and peer interactions in the formative years, Harris, 1995; Scherer, Adams, Carley, \& Wiebe, 1989; Schmitt-Rodermund, 2004, or promotive external business conditions or role models in the occupational career) on the development of an entrepreneurial mindset across childhood, adolescence, and adulthood. A central part in the model is early characteristic adaptations in childhood/adolescence as precursor of an entrepreneurial mindset in adulthood, and through which biologically based propensities and ecological conditions exert an effect. According to a modern understanding of personality development (McAdams \& Pals, 2006), they are called characteristic adaptations because they arise from interactions with the context (e.g., parents or peers) via processes of adaptation, but these interactions occur in a characteristic manner because they are influenced by rather stable and biologically based characteristics (e.g., temperament, broad personality traits). Examples of such early characteristic adaptations are age-appropriate early "entrepreneurial" competencies (e.g., leadership, invention, and commercial skills, Schmitt-Rodermund, 2004, 2007) and motivational aspects (e.g., self-efficacy beliefs, self-esteem, values, goals, aspirations, and expectancies). Consistent with talent research (Bloom, 1985; Csikszentmihalyi, Rathunde, \& Whalen, 1993), such early characteristics and achievements in turn build the developmental basis for the shaping of an entrepreneurial mindset in adulthood (e.g., via competence growth and deliberate practice, Ericsson \& Charness, 1994). Such a mindset in adulthood is also influenced by biologically based propensities and ecological conditions that are present in adulthood (e.g., adult personality make-up; availability of role models), but these biological and ecological factors reach back to the formative years as well. For example, biological factors show stability (but also certain degrees of plasticity across the life span, e.g., in personality development or with respect to epigenetic processes such as differential gene expression, Meaney, 2010). The ecological opportunity structure should also show some stability and continuity across time, for example in terms of financial background in the family of origin and related cumulative (dis)advantage over the life course.
Consistent with life span psychology stressing that at virtually each life stage there is potential for change and growth (Baltes et al., 2006), the model also acknowledges that entrepreneurial development does not stop in adulthood but is, in principle, an ongoing process of learning and adaptation. For example, numerous studies demonstrated that people do not only select (or get selected into) their work environments according to their personal characteristics (e.g., competencies, interests, personality make-up). They also get socialized through work experiences (Frese, 1982) (e.g., entrepreneurs learn by doing, Cope, 2005), which, in our case, involves mutual transactions between the entrepreneurial mindset and entrepreneurial behavior over time. Acknowledging the fundamental relevance of early socialization, we argue, however, that the most crucial periods in entrepreneurial development are the formative years (childhood and adolescence). Such an early development may affect, for example, how entrepreneurs learn by doing (Krueger, 2007). This emphasis on the early years is consistent with (1) developmental stage theories, locating fundamental aspects of successive personality and cognitive development (e.g., identity formation) in childhood and adolescence (e.g., Erikson, 1959; Havighurst, 1972; Super, 1980), (2) research hinting at early critical and sensible phases in skill growth (e.g., Heckman, 2006), and (3) theories stressing that entrepreneurial thinking and acting in adulthood involves "deep" cognitive structures that develop early in life (Krueger, 2007; see also McClelland, 1961). Pointing to the interplay between selection and socialization, studies further indicate that work experiences deepen and sustain those personal characteristics that led to those experiences in the first place. Roberts, Caspi, and Moffit (2003) interpret such findings as suggesting that "work experiences ... make us more of who we already are" (p. 592).

Finally, we must acknowledge that such a model of entrepreneurial development, as an attempt to provide a broad integrative framework of a "developmental science of entrepreneurship", is of course somewhat simplified. Human development is very complex; along the culturally-framed age-graded developmental tasks (Havighurst, 1972), it involves manifold interactions, and even transactions at (and between) biological, neurological, behavioral, and environmental levels (Gottlieb, 2003). For example, for the sake of clarity and simplicity, we do not explicitly model interactions between biologically based propensities and contextual structures in our model, but such links might be relevant too. Schmitt-Rodermund (2007) 
showed that a subsequent entrepreneurial career in adulthood, as developmental outcome, was particularly likely when both came together during adolescence, an entrepreneurial personality structure and a supportive (authoritative) parenting style as stimulating environment.

We now briefly summarize the articles included in this Thematic Issue and explain their relevance for our model. Lerner and Damon's (2012) theoretical article is an attempt to provide a basic introduction to the topic of entrepreneurial development in adolescence. This can be seen as a specification of our model for the specific developmental period of adolescence. Applying a relational developmental systems approach, they focus on adolescent development as embedded in context systems, and stress the importance of person-centered approaches (in contrast to variable-centered approaches) and true developmental data (e.g., longitudinal data capturing individual development) when studying developmental pathways and person-context exchanges in this field. They also give an overview of existing developmental research on youth entrepreneurship and make a case for the inclusion of developmental questions in the entrepreneurship research agenda. They end with a short description of their own ongoing research project, the so-called Youth Entrepreneurship Study, which will examine entrepreneurial development among adolescents living in the U.S.

Pointing to the relevance of biology in entrepreneurial development (e.g., biologically based propensities), the article by Quaye, Nicolaou, Shane, and Mangino (2012) examines genetic factors and extends past behavioral genetic research, which indicates a genetic underpinning of entrepreneurial behavior, by applying a molecular genetic perspective. This is an important step ahead because their study looks at genes rather than at heritability estimates for populations. Using an adult twin sample from the UK, Quaye et al. conduct a genome-wide association (GWA) study to examine whether and which DNA sequences are associated with entrepreneurship in adulthood. GWA studies, as the dominant approach in current molecular genetics, investigate the entire genome to identify those DNA sequences that relate to a specific trait or behavior (e.g., entrepreneurship) (Plomin, in press). Quaye et al. identify some promising associations between certain genetic variants and entrepreneurship (although the effects are quite small, which is common in such GWA studies). The authors also make important suggestions on how future research could advance the field of molecular genetics of entrepreneurship on the basis of their analyses (e.g., by employing new genome portioning methods). Such research could consider gene-gene and gene-environment interactions to further explore the role of genes, but also the role of the environment in entrepreneurial development (e.g., regarding the possibility of early interventions to promote entrepreneurial mindsets) (Plomin, in press). Existing behavioral genetic research indicates that environmental factors "explain much of the variance in entrepreneurial activity, providing strong evidence of the effect of environmental factors on the propensity to become an entrepreneur" (Nicolaou et al., 2008, p. 174). This was also shown in many other genetic studies investigating other traits and behaviors. Together, these studies, somewhat paradoxically, give the environment a unique role, which is also illustrated in epigenetic research (Meaney, 2010). This calls for developmentalcontextual perspectives that incorporate biological factors, which is a key proposition of developmental science.

The article by Obschonka, Duckworth, Silbereisen, and Schoon (2012) targets early precursors of entrepreneurship, with a special focus on social competencies as early characteristic adaptations. The authors utilize different datasets (stemming from Germany and the UK) and methods (e.g., prospective and retrospective designs) to test whether early social competencies in childhood and adolescence, and underlying developmental processes, relate to different aspects of entrepreneurship in adulthood (e.g., entrepreneurial intention, career choice, and success). The overall finding is that early social competencies indeed predict later entrepreneurship, which hints at the importance of skill growth in this domain. Past research already indicated that social competencies are crucial for entrepreneurship (e.g., for starting one's own business), but, as these studies usually did not take a developmental perspective, it is unclear so far whether higher levels of social competencies among entrepreneurs (vs. nonentrepreneurs) may result from socialization through (entrepreneurial) work or from earlier developmental processes.

What is the role of the school context in entrepreneurial development? Are future business owners "rule-breakers" in school; unruly students who have little attachment to their schools, low educational ambitions, and trouble obeying their teachers? These questions are tackled in Saw and Schneider's (2012) article, which presents data collected within 
a nationally longitudinal study of U.S. adolescents and their subsequent career development. Consistent with prior research (Falck et al., 2012), the authors find an entrepreneurial career in adulthood to be forecasted by entrepreneurial career intentions assessed in adolescence, which is another early characteristic adaptation in the language of our model. Although the pattern of results indicate some gender differences, the central findings of their study indicate that budding entrepreneurs indeed hold a weaker attachment to school, but, and this is also important, they do not completely reject education (they still show some level of engagement). If these findings on these schoolrelated characteristic adaptations can be replicated then they have important implications for entrepreneurial education programs. The authors conclude that budding entrepreneurs are not early "rule-breakers" in a negative sense (e.g., showing anti-social behavior or rejecting formalized school rules and routines), as suggested by an existing retrospective study that compared entrepreneurs and managers (Zhang \& Arvey, 2009). They are not the "bad guys" with maladaptive development but rather show quite adaptive early development. Interestingly, this is also the story told in the article by Obschonka et al. (2012), which does not find an indication for stronger early anti-social tendencies among budding entrepreneurs.

Consistent with ecological systems theory (Bronfenbrenner, 1979), entrepreneurial development also takes place in broader macro contexts (e.g., political or economic conditions of a particular country), in which developmental contexts more proximal to the individual (e.g., parents or peer interactions as micro contexts) are embedded. These different layers of developmental contexts develop over historical time (e.g., social and economic change) and over the life course (e.g., while parents are a crucial micro context in childhood, peers and romantic partners become more important later in life). With such a contextual systems view in mind, Fritsch and Rusakova (2012) are interested in the interplay of micro and macro contexts in which entrepreneurial development takes place. Using the example of the divided Germany before its reunification in 1990, they analyze data from a nationally representative household panel that were collected after 1990 and study the effect of early parental role models, as a stimulating micro context, and its dependence on macro contextual conditions (socialist regime in East Germany vs. market economy in West Germany). The authors try to explain self-employment status in adulthood in the post-unified Germany. Their results are of relevance for developmentalists because they point attention to the (changing) macro contexts. Their results seem to indicate that the supportive role of an entrepreneurial work background of parents in entrepreneurial development (ecological opportunity structure) depends on the macro context (and on related education strategies in schools). The early contextual stimulation of entrepreneurial parents (e.g., by providing entrepreneurial role models), which was already indicated in prior research studying individuals that grew up in Western market economies (e.g., Laspita, Breugst, Heblich, \& Patzelt, 2012; SchmittRodermund, 2004), seem to be effectless among East Germans that grew up with socialist indoctrination in the highest educational sector, because this indoctrination may have reduced the (promotive) parental influence. Such research reminds us that macro contextual conditions (and different context layers and their interactions) should not be disregarded when studying entrepreneurial development because they are part of the ecological opportunity structure (McClelland, 1961).

Taking a longitudinal perspective is not only fruitful when examining early precursors and the making of an entrepreneur; it should also be considered when assessing entrepreneurial behavior in adulthood from a person-centered perspective - when looking at the entrepreneurial career as a whole (Dyer, 1994). Only then will we get the bigger picture of what the enterprising individual actually achieves and how sequences of starting and growing businesses are embedded in the entire occupational career. The study by Zacher, Biemann, Gielnik, and Frese (2012) is important because it identifies characteristic patterns of entrepreneurial careers by looking at sequences of self-employment over a period of more than 20 years. Like Fritsch and Rusakova (2012), they utilize nationally representative data from the German household panel, but it should be kept in mind that they focus on a specific subsample. Using an optimal matching analysis, they find five career patterns among the self-employed (e.g., continuous self-employment). Consistent with the logic of our model, they can show that (some of) these selfemployment patterns were predictable by individual characteristics (sociodemographics and personality differences). For example, they consider the predictive role of the Big Five personality traits, which, in the language of our model, are biologically based propensities that are rather stable over time and that should affect the entrepreneurial career via characteristic adaptations in the course of a person's development. 
What can we learn from these six articles? First and foremost, one gets an impression of the currently utilized research strategies, the different perspectives taken, and the multidisciplinarity in the field. More importantly, these works, taken together, illustrate the relevance of approaching entrepreneurship with a developmental science approach that considers biological, psychosocial, behavioral, and contextual factors, and a longitudinal age-graded perspective with a special focus on the formative years (without forgetting that human development is a lifelong process). This Thematic Issue contributes to the growing empirical evidence indicating that entrepreneurship can indeed be understood as a developmental outcome, with underlying successive and systematic change from early developmental stages on. In a nutshell, biological factors (e.g., the genetic make-up) matter, and the context (and its different layers from micro to macro contexts) is crucial too, which calls for frameworks that integrate biology and context, like our model of entrepreneurial development (Fig. 1). This is not the full story, however, because individuals are active (co-)producers of their own development (Brandtstädter, 2006; Lerner, 2006), which points to the role of human agency throughout a person's entrepreneurial development. In this vein, early activities, competencies, interests, and motivational aspects (which arise from human agency and characteristic exchanges with the context) build early developmental achievements and early steps, on which later developmental processes leading to (successful) entrepreneurship in adulthood also build, as described in our model.

However, we are only at the beginning because the field is so young and still emerging. Much more needs to be done before research can propose concrete implications for policy and education. Nonetheless, empirical evidence suggesting that a developmental perspective that takes into account the formative years is indeed crucial for programs aiming to stimulate entrepreneurial mindsets is growing. What is clearly needed, for example, is intensified effort with regard to research methods, preferably using longitudinal designs, theoretical approaches, and analyzing tools that catch (some of) the complexity of entrepreneurial development across the life span and that consider a modern understanding of developmental science. Finally, our hope is that this Thematic Issue might contribute to an increased interest in entrepreneurial development among researchers, educators, and practitioners alike. As demonstrated in this set of studies, there is considerable potential in enriching today's research dealing with biology, mind, and behavior of (potential) entrepreneurs through a developmental perspective and a developmental science framework that help to integrate the diversified research on enterprising individuals (Sarasvathy \& Venkataraman, 2011).

Finally, we want to thank all those who responded to our call for abstracts, although in the end not all proposals could be included. The reviewers, which are listed below, deserve our special gratitude for providing high-quality reviews and their willingness to work to a strict timeline. We were happy to get the commitment of experts from different fields including entrepreneurship, psychology, career development, genetics, management, and economics: Jens B. Asendorpf (Humboldt University of Berlin, Germany), Robert A. Baron (Oklahoma State University, USA), Uwe Cantner (University of Jena, Germany), Oliver Falck (Ludwig Maximilian University of Munich, Germany), Jerome A. Katz (Saint Louis University, USA), Alexander Kritikos (German Institute for Economic Research, Germany), Thomas Lang-von Wins (Bundeswehr University Munich, Germany), Anne C. Petersen (University of Michigan, USA), Robert Plomin (King's College London, UK), Andreas Rauch (University of Exeter, UK), Eva SchmittRodermund (University of Jena, Germany), Vladimir Skorikov (University of Hawaii, USA), Michael Stuetzer (Queensland University of Technology, Australia), Fred W. Vondracek (Pennsylvania State University, USA), Karina Weichold (University of Jena, Germany), and Peter Visscher (University of Queensland, Australia).

Martin Obschonka and Rainer K. Silbereisen, Guest Editors

\section{References}

Baltes, P. B., Reuter-Lorenz, P. A., \& Rösler, F. (2006). Lifespan development and the brain. The perspective of biocultural coconstructivism. New York: Cambridge University Press.

Bloom, B. S. (Ed.) (1985). Developing talent in young people. New York: Ballentine Books.

Brandtstädter, J. (2006). Action perspectives on human development. In W. Damon \& R. M. Lerner (Eds.), Handbook of child psychology: Vol. 1. Theoretical models of human development (pp. 516-568). Hoboken, NJ: Wiley.

Bronfenbrenner, U. (1979). The ecology of human development: Experiments by nature and design. Cambridge: Harvard University Press.

Clausen, J. S. (1991). Adolescent competence and the shaping of the life course. American Journal of Sociology, 96, 805-842. 
Cope, J. (2005). Toward a dynamic learning perspective of entrepreneurship. Entrepreneurship: Theory \& Practice, 29, 373394.

Csikszentmihalyi, M., Rathunde, K., \& Whalen, S. (1993). Talented teenagers: The roots of success and failure. Cambridge: Cambridge University Press.

Dyer, W. G. (1994). Toward a theory of entrepreneurial careers. Entrepreneurship: Theory and Practice, 19, 7-21.

Ericsson, K. A., \& Charness, N. (1994). Expert performance: Its structure and acquisition. American Psychologist, 49, 725-747.

Erikson, E. H. (1959). Identity and the life cycle. New York: International Universities Press.

Falck, O., Heblich, S., \& Luedemann, E. (2012). Identity and entrepreneurship: Do school peers shape entrepreneurial intentions? Small Business Economics, 39(1), 39-59.

Frese, M. (1982). Occupational socialization and psychological development: An underemphasized research perspective in industrial psychology. Journal of Occupational Psychology, 55, 209-224.

Fritsch, M., \& Rusakova, A. (2012). Self-employment after socialism: Intergenerational links, entrepreneurial values, and human capital. International Journal of Developmental Science, 6, 167175.

Gottlieb, G. (2003). On making behavioral genetics truly developmental. Human Development, 46, 337-355.

Harris, J. R. (1995). Where is the child's environment? A group socialization theory of development. Psychological Review, 102, 458-489.

Havighurst, R. J. (1972). Developmental tasks and education (3rd ed.). New York: David McKay Company.

Heckman, J. J. (2006). Skill formation and the economics of investing in disadvantaged children. Science, 312, 1900-1902.

Hisrich, R., Langan-Fox, J., \& Grant, S. (2007). Entrepreneurship research and practice: A call to action for psychology. American Psychologist, 62, 575-589.

Isaacson, W. (2011). Steve Jobs: A biography. New York: Simon \& Schuster.

Kahnemann, D. (2011). Thinking, fast and slow. New York: Farras, Straus, \& Giroux.

Krueger, N. F. (2007). What lies beneath? The experiential essence of entrepreneurial thinking. Entrepreneurship: Theory \& Practice, 31, 123-138.

Laspita, S., Breugst, N., Heblich, S., \& Patzelt, H. (2012). Intergenerational transmission of entrepreneurial intentions. Journal of Business Venturing, 27, 414-435.

Lerner, R. M. (2006). Developmental science, developmental systems, and contemporary theories of human development. In R. M. Lerner (Ed.), Theoretical models of human development: Vol. 1. Handbook of child psychology (pp. 1-17). Hoboken, NJ: Wiley.

Lerner, R. M., \& Damon, W. (2012). Entrepreneurship in adolescence: A relational developmental systems approach. International Journal of Developmental Science, 6, 117-126.

McAdams, D. P., \& Pals, J. L. (2006). A new Big Five: Fundamental principles for an integrative science of personality. American Psychologist, 61, 204-217.

McClelland, D. (1961). The achieving society. Princeton, NJ: Van Nostrand.

Meaney, M. J. (2010). Epigenetics and the biological definition of gene $\times$ environment interactions. Child Development, 81, 41-79.
Nicolaou, N., Shane, S., Cherkas, L., Hunkin, J., \& Spector, T. (2008). Is the tendency to engage in entrepreneurship genetic? Management Science, 54, 167-179.

Obschonka, M. (2011). Entrepreneurship as developmental outcome: The entrepreneurial process and the life span perspective of human development. Unpublished Ph.D. thesis, University of Jena, Germany.

Obschonka, M., Silbereisen, R. K., \& Schmitt-Rodermund, E. (2010). Entrepreneurial intention as developmental outcome. Journal of Vocational Behavior, 77, 63-72.

Obschonka, M., Silbereisen, R. K., \& Schmitt-Rodermund, E. (2011). Entrepreneurial success as developmental outcome: A path model from a life-span perspective of human development. European Psychologist, 16, 174-186.

Obschonka, M., Duckworth, K., Silbereisen, R. K., \& Schoon, I. (2012). Social competencies in childhood and adolescence and entrepreneurship in young adulthood: A two-study analysis. International Journal of Developmental Science, 6, 137-150.

Plomin, R. (in press). Child development and molecular genetics: 14 years later. Child Development.

Quaye, L., Nicolaou, N., Shane, S., \& Mangino, M. (2012). A discovery genome-wide association study of entrepreneurship. International Journal of Developmental Science, 6, 127-135.

Roberts, B. W., Caspi, A., \& Moffitt, T. E. (2003). Work experiences and personality development in young adulthood. Journal of Personality and Social Psychology, 84, 582-593.

Rothbart, M. K. (2011). Becoming who we are: Temperament and personality development. New York: Guilford Press.

Sarasvathy, S. D., \& Venkataraman, S. (2011). Entrepreneurship as method: Open questions for an entrepreneurial future. Entrepreneurship: Theory \& Practice, 35, 113-135

Saw, G. K., \& Schneider, B. (2012). Tracing entrepreneurship orientation in adolescence to business ownership. International Journal of Developmental Science, 6, 151-165.

Scherer, R. F., Adams, J. S., Carley, S. S., \& Wiebe, F. A. (1989). Role model performance effects on development of entrepreneurial career preference. Entrepreneurship: Theory \& Practice, 1, 5371.

Schmitt-Rodermund, E. (2004). Pathways to successful entrepreneurship: Parenting, personality, entrepreneurial competence, and interests. Journal of Vocational Behavior, 65, 498-518.

Schmitt-Rodermund, E. (2007). The long way to entrepreneurship: Personality, parenting, early interests, and competencies as precursors for entrepreneurial activity among the 'Termites'. In R. K. Silbereisen, \& R. M. Lerner (Eds.), Approaches to positive youth development (pp. 205-224). London: Sage.

Shane, S. (2012). Delivering on the promise of entrepreneurship as a field of research. Academy of Management Review, 37, 1020.

Silbereisen, R. K., \& Chen, X. (Eds.). (2010). Human development and social change: Concept and results. London: Sage.

Super, D. E. (1980). A life-span, life-space approach to career development. Journal of Vocational Behavior, 16, 282-298.

The World Bank. (2010). Stepping up skills: For more jobs and higher productivity. Washington D.C.: The World Bank.

Vondracek, F. W., Lerner, R. M., \& Schulenberg, J. E. (1986). Career development: A life-span developmental approach. Hillsdale, $\mathrm{NJ}$ : Erlbaum.

World Economic Forum. (2009). Educating the next wave of entrepreneurs: Unlocking entrepreneurial capabilities to meet the 
global challenges of the 21st century. Geneva, Switzerland: World Economic Forum.

Zacher, H., Biemann, T., Gielnik, M. M., \& Frese, M. (2012). Patterns of entrepreneurial career development: An optimal matching analysis approach. International Journal of Developmental Science, 6, 177-187.

Zhang, Z., \& Arvey, R. D. (2009). Rule breaking in adolescence and entrepreneurial status: An empirical investigation. Journal of Business Venturing, 24, 436-447.

\section{Bio Sketches}

Martin Obschonka is a post-doctoral researcher at the Department of Developmental Psychology and at the Center for Applied Developmental Science, University of Jena, Germany. He is a fellow of the PATHWAYS International Postdoctoral Fellowship Programme for the Comparative Study of Productive Youth Development, funded by the Jacobs Foundation. His research interests include entrepreneurship, social and economic change and adaptive human development, socioecological psychology, and positive psychology.
Rainer K. Silbereisen is Professor and Head of the Department of Developmental Psychology at the University of Jena (Germany), Adjunct Professor of Human Development and Family Studies at the Pennsylvania State University (USA), Director of the Center for Applied Developmental Science, and member of the Board of Governors of the University of Haifa (Israel). He was Chair of the Board of the German Social Science Infrastructure Services (GESIS) and President of the German Psychological Society, the International Society for the Study of Behavioral Development (ISSBD), and the International Union of Psychological Science (IUPsyS). His research interests comprise human development across the life-span, particularly concerning adolescence and early adulthood; impact of social change on individual development; acculturation among immigrants; entrepreneurship; problem behaviour in adolescence; and biobehavioral aspects of adolescent development. 